\title{
Direct Potable Reuse: The Singapore NEWater Project as a Role Model
}

\author{
Djamel Ghernaout ${ }^{1,2 *}$, Noureddine Elboughdiri ${ }^{1,3}$, Abdulaziz Alghamdi ${ }^{4}$ \\ ${ }^{1}$ Chemical Engineering Department, College of Engineering, University of Ha'il, Ha'il, KSA \\ ${ }^{2}$ Chemical Engineering Department, Faculty of Engineering, University of Blida, Blida, Algeria \\ ${ }^{3}$ Département de Génie Chimique de Procédés, Laboratoire Modélisation, Analyse, et Commande des systèmes, Ecole Nationale \\ d'Ingénieurs de Gabès (ENIG), Gabès, Tunisia \\ ${ }^{4}$ Mechanical Engineering Department, College of Engineering, University of Ha'il, Ha'il, KSA \\ Email: *djamel_andalus@hotmail.com
}

How to cite this paper: Ghernaout, D., Elboughdir, N. and Alghamdi, A. (2019) Direct Potable Reuse: The Singapore NEWater Project as a Role Mode. Open Access Library Journal, 6: e5980. https://doi.org/10.4236/oalib.1105980

Received: December 9, 2019

Accepted: December 24, 2019

Published: December 27, 2019

Copyright (c) 2019 by author(s) and Open Access Library Inc.

This work is licensed under the Creative Commons Attribution International License (CC BY 4.0).

http://creativecommons.org/licenses/by/4.0/

\section{(c) (i) Open Access}

\begin{abstract}
In Singapore, indirect potable water reuse has been applied during the last two decades. Now, water reuse furnishes around $30 \%$ of the nation's water request and the well-known NEWater success story has greatly participated in transforming Singapore into a global hydro hub for pioneering novel water techniques. This work discusses the recent technological improvements and the outlooks for water reuse in Singapore as a model. Fields of attentions comprise membrane exploitation (involving forward, reverse and pressure retarded osmosis, as well as membrane bioreactors), advanced oxidation processes, electrochemical methods, and their combination as cost-effective tailored solutions to tackle novel dares as diverse as direct potable reuse. The challenge is to duplicate the Singapore NEWater success story throughout the world. Efforts should be accomplished to generalize such encouraging and rich experience especially in poor countries where humans are dying because of lack of water or due to diseases caused by contaminated water.
\end{abstract}

\section{Subject Areas}

Environmental Sciences, Hydrology

\section{Keywords}

Water Reuse, Direct Potable Reuse, Water Scarcity, Membrane Processes, Wastewater Treatment, Drinking Water

\section{Introduction}

Wastewater may be known as water whose quality has been damaged via agri- 
cultural, industrial or domestic use [1] [2]. Wastewater is considered as the novel oil, focusing attention on the indispensable significance of water as a natural resource, which in several regions is viewed as a gift [3] [4] [5]. In addition to climate modifications, especially global warming, anticipated transferring water accessibility across the Earth, affirming geographical disproportions and menacing to four billion people in areas that are mostly previously weak, measures are needed to reconsider water use models [6] [7] [8].

Singapore confronts several dares: shortage of ground and natural resources, civilian thickly inhabited nature, etc. With global renewable freshwater resources of $0.6 \mathrm{~km}^{3}$ and a population of 5.6 million (i.e., corresponding to less than 110 $\mathrm{m}^{3}$ per capita), Singapore's water case is similar to that of Libya, Jordan or Sudan and causes it by far the most water-scarce state in South East Asia. With reference to past events, Singapore has counted on Malaysia for its freshwater supply but has commenced seeking water reuse as early as the 1970s [9]. Even though at that period, membrane technology [10] [11] [12] [13] was not considered feasible economically, the assiduous technology watch that resulted later conducted to a pilot demonstration in the 1990s pursued in the 2000s by the island-wide achievement of NEWater, the brand name attributed to reclaimed water by Singapore's Public Utilities Board (PUB). These days, four NEWater plants supply in average $30 \%$ of Singapore's water demand, a number that is expected to rise to $55 \%$ by 2060 , at which point of time NEWater production could be as high as 2 million $\mathrm{m}^{3}$ per day [3].

Having recourse to water reuse, which is more energy-efficient than desalination, releases area for more worthy land utilization [3]. Water reuse remains the judicious target to make the nation self-sufficient water-wise that has participated in wider public admission in Singapore than in proximate Australia for instance [14] [15].

Singapore has embraced a quite focused procedure to water reuse with a treatment train incorporating primary sedimentation/activated sludge/microfiltration (MF)/ultrafiltration (UF)/reverse osmosis (RO)/ultraviolet (UV) disinfection [16] [17] [18] [19] [20]. Consequently, the heart technology behind treating water in NEWater is pressure-driven RO, which lets particle removal firstly via size-exclusion by means of pores extending among 0.2 and $0.4 \mathrm{~nm}$ [21]. At this pore dimension, permeate is solid-free, comprising no rising pollutants, metals, salts, viruses or other microbes. However, the drawbacks of RO comprise elevated energy needs and membrane fouling, which are relieved via pre-treatment, containing consecutive steps of primary clarification, biological treatment, and low-pressure MF $(0.1-0.2 \mathrm{~mm}) / \mathrm{UF}(0.01-0.02 \mathrm{~mm})$. In the improbable incident of RO solidity fracture, UV post-treatment guarantees that the permeate stays free of any microbiological content at all times [3]. With this multiple-barrier technique, NEWater exceeds the WHO drinking water quality guidelines [22] at a price under SGD $0.2 / \mathrm{m}^{3}$ and a portion is directed towards industries needing ultrapure water (e.g., in the micro-electronics sector) while 
the remaining enters the reservoirs for remineralization and indirect potable reuse (IPR) [9].

This paper presents the recent technological improvements and the outlooks for water reuse in Singapore as a model. Fields of attentions comprise membrane exploitation (involving forward, reverse and pressure retarded osmosis, as well as membrane bioreactors), advanced oxidation processes (AOPs), electrochemical methods, and their combination as cost-effective tailored solutions to tackle novel dares as diverse as direct potable reuse.

\section{Latest Advance in Water Reuse}

\subsection{Membrane Expansion}

RO composes the central technology at the back of water reuse; however, elevated energy necessity and brine handling make severe hurdles [23]. The prime advantage of RO remains its potential to address salinity elimination. Concerning microorganisms and rising pollutants, it may well be replaced via a more cost-effective multi-barrier procedure involving the integration of biological, adsorption, MF/UF and AOPs [3] [24].

In the group of replacements of $\mathrm{RO}$, the last decade has progressively intensified the potentials of the forward osmosis (FO) and pressure retarded osmosis (PRO) [25]. Throw taking advantage of a draw solution to naturally drive the osmotic process, FO advantages from fundamentally lower energy consumption and fouling propensity as contrasted to RO; nevertheless, the product of $\mathrm{FO}$ is not NEWater but a diluted draw solution that needs secondary treatment. This indicates that FO and RO may not automatically be reciprocally exclusive and actually, they may be integrated for energy optimization with RO concentrate being employed as the draw solution for FO (Figure 1) [3]. This method is essentially favorable for inland water reuse solutions where brine recycling is not a choice. In Singapore, the intrinsic restrictions of FO like the requirement for better membrane materials [26] up to this time shorten its utilizations in the next years. PRO, still, may form a coming approach to produce hydropower from $\mathrm{RO}$ brine as long as firm membranes are advanced that may resist the

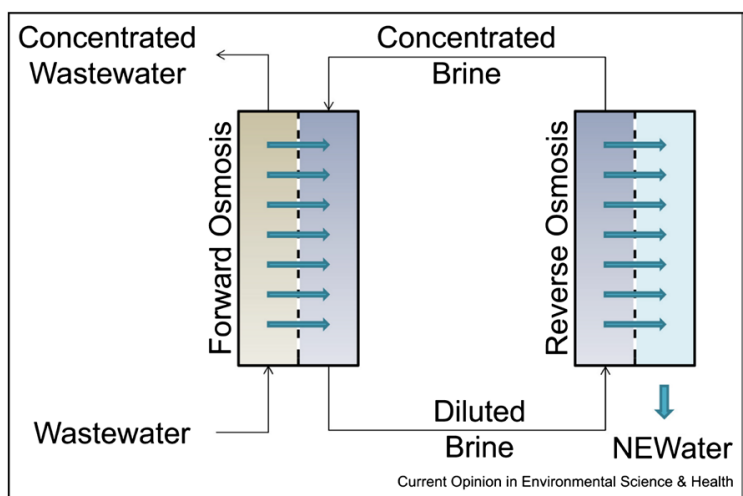

Figure 1. Integrating FO and RO methods for energy optimization. The RO brine would play the role of the draw solution in that NEWater production scheme [3]. 
elevated pressure of concentrated brine [25].

\subsection{Advanced Oxidation Processes (AOPs)}

Founded on the formation of hydroxyl radicals $\left({ }^{\bullet} \mathrm{OH}\right)$, AOPs have been efficiently applied for tertiary treatment of domestic wastewater, single or in integration with additional methods as a piece of a multiple-barrier technology in water reuse programs [3] [27]. In contrast to membranes, AOPs are devastating techniques that occasion the division of constitutional bonds and cause the transformation of the beginning contaminant into numerous intermediates at a percentage bigger than simple methods [28]. As a result, AOPs are usable before membranes methods to reduce fouling or later to eliminate micro-contaminants that may go through. Drawbacks of AOP methods comprise the generation of oxidation by-products [29] that, in defined situations, may gather in water and be more poisonous than the original compound. For instance, $\mathrm{O}_{3} / \mathrm{H}_{2} \mathrm{O}_{2}$ and $\mathrm{UV} / \mathrm{H}_{2} \mathrm{O}_{2}$ may conduct to either the generation or the decomposition of bromate [30], polyfluorinated chemicals [31] or halogenated disinfection by-products [32] [33] [34] [35] following the circumstances. N-Nitrosodimethylamine (NDMA) has been mostly well investigated and was detected to produce only when AOPs are implemented prior to RO [36] [37]. Nevertheless, AOPs can form more-reactive NDMA precursors staying in RO permeate and improving NDMA generation throughout final chloramination [32] [36] [37]. Due to both the AOP injection and the type of matrix play deciding roles, it is indispensable to accurately estimate such influences prior to applying for water reuse [38]. Table 1 presents a list of different AOPs and their benefits and drawbacks [3].

Table 1. AOP juxtaposition [3].

\begin{tabular}{|c|c|c|}
\hline Technique & Benefits & Drawbacks \\
\hline $\begin{array}{l}\text { Ozonation }\left(\mathrm{O}_{3} / \mathrm{H}_{2} \mathrm{O}_{2}\right. \\
\left.\mathrm{O}_{3} / \mathrm{Fe}^{2+}, \mathrm{O}_{3} / \mathrm{Fe}^{2+} / \mathrm{UV}\right)\end{array}$ & Field-proven & $\begin{array}{l}\text { Production of oxidation by-products, air permit needed for } \\
\text { ozone emissions, off-gas treatment system for ozone destruction. } \\
\text { Elevated working prices because of low water solubility. }\end{array}$ \\
\hline $\begin{array}{l}\text { Photolysis }\left(\mathrm{O}_{3} / \mathrm{UV}\right. \\
\left.\mathrm{H}_{2} \mathrm{O}_{2} / \mathrm{UV}\right)\end{array}$ & Field-proven, UV's disinfection impact & $\begin{array}{l}\text { Interference from turbidity. UV's elevated price. UV's restricted } \\
\text { domain. }\end{array}$ \\
\hline $\begin{array}{l}\text { Heterogeneous } \\
\text { photocatalysis } \\
\left(\mathrm{TiO}_{2} / \mathrm{UV}\right)\end{array}$ & $\begin{array}{l}\text { Runs in a larger span of UV than } \\
\text { photolysis like UVA }(300-380 \mathrm{~nm})\end{array}$ & $\begin{array}{l}\text { If } \mathrm{TiO}_{2} \text { is employed as a slurry, a separation stage is needed. } \\
\text { Supported } \mathrm{TiO}_{2} \text { technique depicts promises in this direction; } \\
\text { however, it has to be scaled-up. }\end{array}$ \\
\hline $\begin{array}{l}\text { Traditional Fenton } \\
\text { reaction }\left(\mathrm{H}_{2} \mathrm{O}_{2} / \mathrm{Fe}^{2+}\right)\end{array}$ & $\begin{array}{l}\text { Efficiency not touched via water quality. Greatly } \\
\text { low-priced because of the } \mathrm{H}_{2} \mathrm{O}_{2} \text { elevated solubility. }\end{array}$ & $\begin{array}{l}\text { No full-scale usage. Optimal } \mathrm{pH} \sim 3.0^{*} \text {. Forms elevated } \\
\text { quantities of Fe [39] sludge. }\end{array}$ \\
\hline
\end{tabular}

*(Solar) photo-Fenton has been largely tried during this decade as tertiary treatment technique for municipal wastewater reuse. Further, it may be used under more moderate circumstances ( $\mathrm{pH} 5$ - 6, lower concentrations of $\mathrm{Fe}$ and $\mathrm{H}_{2} \mathrm{O}_{2}$ ) [40]. This is due to the elimination of pollutants of emerging concern (frequently found in the order of $\mathrm{ng} / \mathrm{L}$ ) and microbial demobilization attributed to the smaller quantity of hydroxyl radicals formed contrasted to $\mathrm{pH} 3$ method is enough. Further, employing complexing/chelating agents has been successfully studied too [41]. 


\subsection{Electrochemical Technologies}

Electrochemistry is more and more viewed as a central knowledge for expanding a possible society from fuel cells to waste electrochemical oxidation, desalination, and water reuse [42] [43] [44]. Electrochemical AOPs are magnetizing many of the awareness, thanks to their numerous benefits, comprising employing a more hygienic reagent (electricity), potential to attain outstanding levels of mineralization, versatility, elevated energy effectiveness [45], amenability of automation and safety [46] [47] [48] [49]. As shown in Table 1, electro-Fenton is fast rising as the most encouraging between electrochemical techniques [50] [51], particularly via the integration with nanomaterials like graphene [52] [53] or boron-doped diamond (BDD) to boost anodic oxidation as an extra source of $\bullet \mathrm{OH}[3]$ [54].

In opposition to different membrane techniques, electrodialysis (ED) depends on charge exclusion and remains a strictly and economically feasible replacement to RO for brackish water desalination, particularly for small facilities [55] [56]. The less rigorous feed quality for ED as contrasted to RO participates in lower the pre-treatment costs [3]. On the other hand, capacitive deionization has proved the capacity to elevate water recovery from RO brine even with cleaning troubles [9] [57] [58].

\section{Outlooks}

\subsection{Membrane Bioreactor}

In Singapore, the following procedure for water reuse will be the expansion of the membrane bioreactor (MBR) [3]. This biological technique integrates the advantages of secondary treatment and MF/UF in one device, with the major merits being a compact structure and consistently good effluent quality. In Singapore, this MBR-RO technique has previously been investigated at the pilot stage [59]. A new expansion remains the FO-MBR accompanied by the benefit of energy efficiency [60]; however, the obstacle of low flux and augmented salinity over time inside the bioreactor, which may negatively touch sludge viability [61].

\subsection{Direct Potable Reuse}

Direct potable reuse (DPR) is considered as the novel limit of water reuse [3] [62] [63] [64]. The fundamental feature for such a strategy to triumph is treatment boost in a multiple-barrier path, which can conduct to the almost not available likelihood of insufficiency [65] [66]. Singapore possesses several benefits to put into action DPR. First, the PUB before now runs the full water cycle from potable water to wastewater treatment. Second, the administration of NEWater in Singapore has previously confirmed to be reliable over several years. For instance, over 300 persistent organic pollutants [67] [68] [69] [70] are previously routinely controlled [9]. At present, it is easy to control a large number of these chemicals at levels as low as parts per trillion [71]. 


\section{Conclusions}

The main points drawn from this work may be given as:

1) The success story of Singapore NEWater mirrors the total semi-permanent planning of the city-state in terms of sustainability. There is a necessity to persist in expanding water techniques and original reuse programs for Singapore. The secret is combining oriented merged solutions joining advanced degradation and separation techniques and their utilization at different levels to address diverse requests.

2) The challenge is to duplicate the Singapore NEWater success story throughout the world. Efforts should be accomplished to generalize such encouraging experience especially in poor countries where humans are dying because of lack of water.

\section{Conflicts of Interest}

The authors declare no conflicts of interest regarding the publication of this paper.

\section{References}

[1] Asano, T. (2002) Water from (Waste) Water-The Dependable Water Resource (the 2001 Stockholm Water Prize Laureate Lecture). Water Science and Technology, 45, 23-33. https://doi.org/10.2166/wst.2002.0137

[2] Ghernaout, D., Elboughdiri, N. and Al Arni, S. (2019) Water Reuse (WR): Dares, Restrictions, and Trends. Applied Engineering, 3, 159-170.

[3] Lefebvre, O. (2018) Beyond NEWater: An Insight into Singapore's Water Reuse Prospects. Current Opinion in Environmental Science \& Health, 2, 26-31. https://doi.org/10.1016/j.coesh.2017.12.001

[4] Ghernaout, D., Ghernaout, B. and Naceur, M.W. (2011) Embodying the Chemical Water Treatment in the Green Chemistry-A Review. Desalination, 271, 1-10. https://doi.org/10.1016/j.desal.2011.01.032

[5] Ghernaout, D. (2017) Environmental Principles in the Holy Koran and the Sayings of the Prophet Muhammad. American Journal of Environmental Protection, 6, 75-79. https://doi.org/10.11648/j.ajep.20170603.13

[6] Mekonnen, M.M. and Hoekstra, A.Y. (2016) Four Billion People Facing Severe Water Scarcity. Science Advances, 2, 1-6. https://doi.org/10.1126/sciadv.1500323

[7] Ghernaout, D. and Ghernaout, B. (2012) On the Concept of the Future Drinking Water Treatment Plant: Algae Harvesting from the Algal Biomass for Biodiesel Production-A Review. Desalination and Water Treatment, 49, 1-18. https://doi.org/10.1080/19443994.2012.708191

[8] Ghernaout, D. (2013) The Best Available Technology of Water/Wastewater Treatment and Seawater Desalination: Simulation of the Open Sky Seawater Distillation. Green and Sustainable Chemistry, 3, 68-88. https://doi.org/10.4236/gsc.2013.32012

[9] Lee, H. and Tan, T.P. (2016) Singapore's Experience with Reclaimed Water: NEWater. International Journal of Water Resources Development, 32, 611-621. https://doi.org/10.1080/07900627.2015.1120188

[10] Ghernaout, D., El-Wakil, A., Alghamdi, A., Elboughdiri, N. and Mahjoubi, A. 
(2018) Membrane Post-Synthesis Modifications and How It Came about. International Journal of Advanced and Applied Sciences, 5, 60-64. https://doi.org/10.21833/ijaas.2018.02.010

[11] Ghernaout, D., Alshammari, Y., Alghamdi, A., Aichouni, M., Touahmia, M. and Ait Messaoudene, N. (2018) Water Reuse: Extenuating Membrane Fouling in Membrane Processes. International Journal of Environmental Chemistry, 2, 1-12. https://doi.org/10.11648/j.ajche.20180602.12

[12] Ghernaout, D. and El-Wakil, A. (2017) Requiring Reverse Osmosis Membranes Modifications: An Overview. American Journal of Chemical Engineering, 5, 81-88. https://doi.org/10.11648/j.ajche.20170504.15

[13] Ghernaout, D. (2017) Reverse Osmosis Process Membranes Modeling: A Historical Overview. Journal of Civil, Construction and Environmental Engineering, 2, 112-122.

[14] Ching, L. and Yu, D.J.H. (2010) Turning the Tide: Informal Institutional Change in Water Reuse. Water Policy, 12, 121-134. https://doi.org/10.2166/wp.2010.117

[15] Ghernaout, D., Elboughdiri, N. and Ghareba, S. (2019) Drinking Water Reuse: One-Step Closer to Overpassing the "Yuck Factor". Open Access Library Journal, 6, e5895. https://doi.org/10.4236/oalib.1105895

[16] Ghernaout, D. and Ghernaout, B. (2010) From Chemical Disinfection to Electrodisinfection: The Obligatory Itinerary? Desalination and Water Treatment, 16, 156-175. https://doi.org/10.5004/dwt.2010.1085

[17] Ghernaout, D., Naceur, M.W. and Aouabed, A. (2011) On the Dependence of Chlorine By-Products Generated Species Formation of the Electrode Material and Applied Charge during Electrochemical Water Treatment. Desalination, 270, 9-22. https://doi.org/10.1016/j.desal.2011.01.010

[18] Ghernaout, D., Alghamdi, A. and Ghernaout, B. (2019) Microorganisms' Killing: Chemical Disinfection vs. Electrodisinfection. Applied Engineering, 3, 13-19.

[19] Ghernaout, D. (2019) Greening Electrocoagulation Process for Disinfecting Water. Applied Engineering, 3, 27-31.

[20] Ghernaout, D., Badis, A., Ghernaout, B. and Kellil, A. (2008) Application of Electrocoagulation in Escherichia coli Culture and Two Surface Waters. Desalination, 219, 118-125. https://doi.org/10.1016/j.desal.2007.05.010

[21] Košutić, K. and Kunst, B. (2002) Removal of Organics from Aqueous Solutions by Commercial RO and NF Membranes of Characterized Porosities. Desalination, 142, 47-56. https://doi.org/10.1016/S0011-9164(01)00424-6

[22] PUB (Public Utilities Board) (2002) In Singapore Water Reclamation Study: Expert Panel Review and Findings, NEWater Expert Panel.

[23] Ghernaout, D. (2019) Brine Recycling: Towards Membrane Processes as the Best Available Technology, Applied Engineering, 3, 71-84.

[24] Ghernaout, D. (2019) Reviviscence of Biological Wastewater Treatment: A Review. Applied Engineering, 3, 46-55.

[25] Chung, T.S., Luo, L., Wan, C.F., Cui, Y. and Amy, G. (2015) What Is Next for Forward Osmosis (FO) and Pressure Retarded Osmosis (PRO). Separation and Purification Technology, 156, 856-860. https://doi.org/10.1016/j.seppur.2015.10.063

[26] Han, G., Cheng, Z.L. and Chung, T.-S. (2017) Thin-Film Composite (TFC) Hollow Fiber Membrane with Double-Polyamide Active Layers for Internal Concentration Polarization and Fouling Mitigation in Osmotic Processes. Journal of Membrane Science, 523, 497-504. https://doi.org/10.1016/j.memsci.2016.10.022 
[27] Ghernaout, D. (2013) Advanced Oxidation Phenomena in Electrocoagulation Process: A Myth or a Reality? Desalination and Water Treatment, 51, 7536-7554. https://doi.org/10.1080/19443994.2013.792520

[28] Cheng, L., Zhang, T., Vo, H., Diaz, D., Quanrud, D., Arnold, R.G. and Sáez, A.E. (2017) Effectiveness of Engineered and Natural Wastewater Treatment Processes for the Removal of Trace Organics in Water Reuse. Journal of Environmental Engineering, 143, 18-36. https://doi.org/10.1061/(ASCE)EE.1943-7870.0001214

[29] Boucherit, A., Moulay, S., Ghernaout, D., Al-Ghonamy, A.I., Ghernaout, B., Naceur, M.W., Ait Messaoudene, N., Aichouni, M., Mahjoubi, A.A. and Elboughdiri, N.A. (2015) New Trends in Disinfection By-Products Formation upon Water Treatment. Journal of Research \& Developments in Chemistry, 2015, Article ID: 628833. https://doi.org/10.5171/2015.628833

[30] Bourgin, M., Borowska, E., Helbing, J., Hollender, J., Kaiser, H.-P., Kienle, C., McArdell, C.S., Simon, E. and von Gunten, U. (2017) Effect of Operational and Water Quality Parameters on Conventional Ozonation and the Advanced Oxidation Process $\mathrm{O}_{3} / \mathrm{H}_{2} \mathrm{O}_{2}$ : Kinetics of Micropollutant Abatement, Transformation Product and Bromate Formation in a Surface Water. Water Research, 122, 234-245. https://doi.org/10.1016/j.watres.2017.05.018

[31] Anumol, T., Dagnino, S., Vandervort, D.R. and Snyder, S.A. (2016) Transformation of Polyfluorinated Compounds in Natural Waters by Advanced Oxidation Processes. Chemosphere, 144, 1780-1787. https://doi.org/10.1016/j.chemosphere.2015.10.070

[32] Zeng, T., Plewa, M.J. and Mitch, W.A. (2016) N-Nitrosamines and Halogenated Disinfection By-Products in U.S. Full Advanced Treatment Trains for Potable Reuse. Water Research, 101, 176-186. https://doi.org/10.1016/j.watres.2016.03.062

[33] Ghernaout, D. and Elboughdiri, N. (2019) Mechanistic Insight into Disinfection Using Ferrate (VI). Open Access Library Journal, 6, e5946. https://doi.org/10.4236/oalib.1105946

[34] Ghernaout, D. (2017) Water Treatment Chlorination: An Updated Mechanistic Insight Review. Chemistry Research Journal, 2, 125-138.

[35] Ghernaout, D. (2018) Disinfection and DBPs Removal in Drinking Water Treatment: A Perspective for a Green Technology. International Journal of Advanced and Applied Sciences, 5, 108-117. https://doi.org/10.21833/ijaas.2018.02.018

[36] Sgroi, M., Roccaro, P., Oelker, G.L. and Snyder, S.A. (2015) N-Nitrosodimethyl Amine (NDMA) Formation at an Indirect Potable Reuse Facility. Water Research, 7, 174-183. https://doi.org/10.1016/j.watres.2014.11.051

[37] Sgroi, M., Vagliasindi, F.G.A., Snyder, S.A. and Roccaro, P. (2018) N-Nitrosodimethylamine (NDMA) and Its Precursors in Water and Wastewater: A Review on Formation and Removal. Chemosphere, 191, 685-703. https://doi.org/10.1016/j.chemosphere.2017.10.089

[38] Schindler Wildhaber, Y., Mestankova, H., Scharer, M., Schirmer, K., Salhi, E. and von Gunten, U. (2015) Novel Test Procedure to Evaluate the Treatability of Wastewater with Ozone. Water Research, 75, 324-335. https://doi.org/10.1016/j.watres.2015.02.030

[39] Ghernaout, D. (2017) The Holy Koran Revelation: Iron Is a "Sent Down" Metal. American Journal of Environmental Protection, 6, 101-104. https://doi.org/10.11648/j.ajep.20170604.14

[40] Klamerth, N., Rizzo, L., Malato, S., Maldonado, M.I., Agüera, A. and Fernández-Alba, A.R. (2010) Degradation of Fifteen Emerging Contaminants at 
mg/L Initial Concentrations by Mild Solar Photo-Fenton in MWTP Effluents. Water Research, 44, 545-554. https://doi.org/10.1016/j.watres.2009.09.059

[41] Bianco, A., Polo Lopez, M.I., Fernandez Ibanez, P., Brigante, M. and Mailhot, G. (2017) Disinfection of Water Inoculated with Enterococcus faecalis Using Solar/Fe(III)EDDS- $\mathrm{H}_{2} \mathrm{O}_{2}$ or $\mathrm{S}_{2} \mathrm{O}_{8}^{2-}$ Process. Water Research, 118, 249-260. https://doi.org/10.1016/j.watres.2017.03.061

[42] Ghernaout, D. (2019) Disinfection via Electrocoagulation Process: Implied Mechanisms and Future Tendencies. EC Microbiology, 15, 79-90.

[43] Ghernaout, D. and Elboughdiri, N. (2019) Iron Electrocoagulation Process for Disinfecting Water: A Review. Applied Engineering, 3, 154-158.

[44] Ghernaout, D. and Elboughdiri, N. (2019) Electrocoagulation Process Intensification for Disinfecting Water: A Review. Applied Engineering, 3, 140-147.

[45] Ghernaout, D., Alghamdi, A., Touahmia, M., Aichouni, M. and Ait Messaoudene, N. (2018) Nanotechnology Phenomena in the Light of the Solar Energy. Journal of Energy, Environmental \& Chemical Engineering, 3, 1-8. https://doi.org/10.11648/j.jeece.20180301.11

[46] Ghernaout, D. (2019) Electrocoagulation and Electrooxidation for Disinfecting Water: New Breakthroughs and Implied Mechanisms, Applied Engineering, 3, 125-133.

[47] Ghernaout, D. (2019) Virus Removal by Electrocoagulation and Electrooxidation: New Findings and Future Trends. Journal of Environmental Science and Allied Research, 2019, 85-90. https://doi.org/10.29199/2637-7063/ESAR-202024

[48] Ghernaout, D. (2019) Electrocoagulation Process for Microalgal Biotechnology: A Review. Applied Engineering, 3, 85-94.

[49] Lynn, W., Heron, J. and Mayer, B.K. (2019) Electrocoagulation as a Pretreatment for Electroxidation of E. coli. Water, 11, 2509.

[50] Brillas, E., Sires, I. and Oturan, M.A. (2009) Electro-Fenton Process and Related Electrochemical Technologies Based on Fenton's Reaction Chemistry. Chemical Reviews, 109, 6570-6631. https://doi.org/10.1021/cr900136g

[51] Ghernaout, D. (2017) Microorganisms' Electrochemical Disinfection Phenomena. EC Microbiology, 9, 160-169.

[52] Mousset, E., Ko, Z.T., Syafiq, M., Wang, Z. and Lefebvre, O. (2016) Electrocatalytic Activity Enhancement of a Graphene Ink-Coated Carbon Cloth Cathode for Oxidative Treatment. Electrochimica Acta, 222, 1628-1641. https://doi.org/10.1016/j.electacta.2016.11.151

[53] Mousset, E., Wang, Z., Hammaker, I. and Lefebvre, O. (2016) Physico-Chemical Properties of Pristine Graphene and Its Performance as Electrode Material for Electro-Fenton Treatment of Wastewater. Electrochimica Acta, 214, 217-230. https://doi.org/10.1016/j.electacta.2016.08.002

[54] Mousset, E., Wang, Z. and Lefebvre, O. (2016) Electro-Fenton for Control and Removal of Micropollutants-Process Optimization and Energy Efficiency. Water Science and Technology, 74, 2068-2074. https://doi.org/10.2166/wst.2016.353

[55] Becheleni, E.M.A., Borba, R.P., Seckler, M.M. and Rocha, S.D.F. (2015) Water Recovery from Saline Streams Produced by Electrodialysis. Environmental Technolo$g y$, 36, 386-394. https://doi.org/10.1080/09593330.2014.978898

[56] Liu, R.D., Wang, Y.K., Wu, G., Luo, J.N. and Wang, S.G. (2017) Development of a Selective Electrodialysis for Nutrient Recovery and Desalination during Secondary Effluent Treatment. Chemical Engineering Journal, 322, 224-233. 
https://doi.org/10.1016/j.cej.2017.03.149

[57] Lee, L.Y., Ng, H.Y., Ong, S.L., Tao, G., Kekre, K., Viswanath, B., Lay, W. and Seah, H. (2009) Integrated Pretreatment with Capacitive Deionization for Reverse Osmosis Reject Recovery from Water Reclamation Plant. Water Research, 43, 4769-4777. https://doi.org/10.1016/j.watres.2009.08.006

[58] Tao, G., Viswanath, B., Kekre, K., Lee, L.Y., Ng, H.Y., Ong, S.L. and Seah, H. (2011) RO Brine Treatment and Recovery by Biological Activated Carbon and Capacitive Deionization Process. Water Science and Technology, 64, 77-82. https://doi.org/10.2166/wst.2011.604

[59] Qin, J.-J., Kekre, K.A., Tao, G., Oo, M.H., Wai, M.N., Lee, T.C., Viswanath, B. and Seah, H. (2006) New Option of MBR-RO Process for Production of NEWater from Domestic Sewage. Journal of Membrane Science, 272, 70-77.

https://doi.org/10.1016/j.memsci.2005.07.023

[60] Ghernaout, D. (2019) Greening Cold Fusion as an Energy Source for Water Treatment Distillation: A Perspective. American Journal of Quantum Chemistry and Molecular Spectroscopy, 3, 1-5.

[61] Eyvaz, M., Aslan, T., Arslan, S., Yuksel, E. and Koyuncu, I. (2016) Recent Developments in Forward Osmosis Membrane Bioreactors: A Comprehensive Review. Desalination and Water Treatment, 57, 28610-28645. https://doi.org/10.1080/19443994.2016.1193448

[62] Drewes, J. and Khan, S. (2015) Contemporary Design, Operation, and Monitoring of Potable Reuse Systems. Journal of Water Reuse and Desalination, 5, 1-7. https://doi.org/10.2166/wrd.2014.148

[63] Ghernaout, D. (2017) Water Reuse (WR): The Ultimate and Vital Solution for Water Supply Issues. International Journal of Sustainable Development Research, 3, 36-46. https://doi.org/10.11648/j.ijsdr.20170304.12

[64] Ghernaout, D. (2018) Increasing Trends towards Drinking Water Reclamation from Treated Wastewater. World Journal of Applied Chemistry, 3, 1-9. https://doi.org/10.11648/j.wjac.20180301.11

[65] Pecson, B.M., Triolo, S.C., Olivieri, S., Chen, E.C., Pisarenko, A.N., Yang, C.-C., Olivieri, A., Haas, C.N., Trussell, R.S. and Trussell, R.R. (2017) Reliability of Pathogen Control in Direct Potable Reuse: Performance Evaluation and QMRA of a Full-Scale 1 MGD Advanced Treatment Train. Water Research, 122, 258-268. https://doi.org/10.1016/j.watres.2017.06.014

[66] Ghernaout, D. (2018) Magnetic Field Generation in the Water Treatment Perspectives: An Overview. International Journal of Advanced and Applied Sciences, 5, 193-203. https://doi.org/10.21833/ijaas.2018.01.025

[67] Ghernaout, D., Ghernaout, B. and Kellil, A. (2009) Natural Organic Matter Removal and Enhanced Coagulation as a Link between Coagulation and Electrocoagulation. Desalination and Water Treatment, 2, 203-222. https://doi.org/10.5004/dwt.2009.116

[68] Ghernaout, D. (2014) The Hydrophilic/Hydrophobic Ratio vs. Dissolved Organics Removal by Coagulation: A Review. Journal of King Saud University-Science, 26, 169-180. https://doi.org/10.1016/j.jksus.2013.09.005

[69] Ghernaout, D., Moulay, S., Ait Messaoudene, N., Aichouni, M., Naceur, M.W. and Boucherit, A. (2014) Coagulation and Chlorination of NOM and Algae in Water Treatment: A Review. International Journal of Environmental Monitoring and Analysis, 2, 23-34. https://doi.org/10.11648/j.ijema.s.2014020601.14

[70] Ghernaout, D., Al-Ghonamy, A.I., Boucherit, A., Ghernaout, B., Naceur, M.W., Ait 
Messaoudene, N., Aichouni, M., Mahjoubi, A.A. and Elboughdiri, N.A. (2015) Brownian Motion and Coagulation Process. American Journal of Environmental Protection, 4, 1-15. https://doi.org/10.11648/j.ajeps.s.2015040501.11

[71] Fawell, J. and Ong, C.N. (2012) Emerging Contaminants and the Implications for Drinking Water. International Journal of Water Resources Development, 28, 247-263. https://doi.org/10.1080/07900627.2012.672394 